\title{
Response of Soil Chemical Properties to Application of Organic Manures of Diverse Sources Integrated in Different Ratios with Urea
}

\author{
Mussaddiq Khan Khalil ${ }^{1, ~ *, ~ S u l t a n ~ N a w a z ~}{ }^{1}$, Muhammad Tariq ${ }^{1}$, Anwar Zaman $^{1}$, Saif Ur Rahman ${ }^{1}$, \\ Waqar Ahmad ${ }^{1}$, Farooq Ishaq ${ }^{1}$, Abrar Ahmad ${ }^{2}$ \\ ${ }^{1}$ Department of Soil and Environmental Science, University of Agriculture Peshawar, KPK, Pakistan \\ ${ }^{2}$ Department of Agronomy, University of Agriculture Peshawar, KPK, Pakistan
}

Email address:

mussaddiqSES@gmail.com (M. K. Khalil)

${ }^{*}$ Corresponding author

\section{To cite this article:}

Mussaddiq Khan Khalil, Sultan Nawaz, Muhammad Tariq, Anwar Zaman, Saifur Rahman, Waqar Ahmad, Farooq Ishaq, Abrar Ahmad. Response of Soil Chemical Properties to Application of Organic Manures of Diverse Sources Integrated in Different Ratios with Urea. International Journal of Bioorganic Chemistry. Vol. 5, No. 1, 2020, pp. 5-9. doi: 10.11648/j.ijbc.20200501.12

Received: December 5, 2019; Accepted: December 23, 2019; Published: January 6, 2020

\begin{abstract}
The present research trail was carried out after harvest of maize crop on calcareous soil (19\% lime on w/w basis) of Pakistan, District Nowshera soil series [Piedmont alluvium, silty clay loam, Ustochrept] to study its chemical properties as affected by application of organic manures of different sources integrated with urea. The treatments of the present study were divided into 3 groups based on the combination ratios such as 1:1, 3:1 and 1:0. Total 13 treatments such as: T1=alone Urea (control), T2 [Urea+SSB (1:1)], T3 [Urea+SCB (1:1)], T4 [Urea+PL (1:1)], T5 [Urea+FYM (1:1)], T6 [Urea+SSB (3:1)], T7 [Urea+SCB (3:1)], T8 [Urea+PL (3:1)], T9 [Urea+FYM (3:1)], T10=alone SSB, T11=alone SCB, T12=alone PL, T13=alone FYM were used and each treatment was replicated thrice. The combination ratios of the treatments were based on $\% \mathrm{~N}$ (required amount of $\mathrm{N}$ is $120 \mathrm{~kg} / \mathrm{ha}$ ) received from Urea and organic manures. Results of the experiment revealed that all the treatments have significantly affected $(\mathrm{P}>0.05)$ the soil chemical properties such as $\mathrm{pH}, \mathrm{E}$. $\mathrm{C}$, total nitrogen content and organic matter content while bulk density was non-significant. By comparing various treatments groups, treatments having 1:1 combination ratio (T2, T3, T4 and T5) have shown best results in case of $\mathrm{pH}, \mathrm{E}$. C and nitrogen content of post-harvest soil. They have mediated the $\mathrm{pH}$ and $\mathrm{E}$. $\mathrm{C}$ to levels favorable for plant growth and $\mathrm{N}$ uptake. While in case of organic matter content maximum results were obtained for treatments having combination ratio of 1:0 i-e (T10, T11, T12 and T13). From the present study it was concluded that all the treatments except control have altered the chemical status of soil to a favorable soil enviro responsive microbial activity and plant growth. Such studies on different soil series under different climatic conditions is advised for wide spread application and authorization of results.
\end{abstract}

Keywords: pH, Electrical Conductivity, Bulk Density, Organic Matter, Nitrogen Content

\section{Introduction}

Appropriate fertilizer use leads to increased crop yields and high crop recovery of the applied nutrients. Some elements may be hazardous to soil as well as environment if used in extreme quantities in various forms, i.e. nitrates and phosphates. Efficient fertilization is therefore important in ensuring crops attain maturity within specific growing seasons [1]. Effectiveness of fertilizers therefore depends on the chemical and physical properties, rate and method of application, soil and climatic conditions and the crop species grown [2]. In recent years, there has been an increased use of high mineral fertilizers, mainly for economic reasons. Examples of inorganic fertilizers used include 50\%Urea, diammonium phosphate (DAP) and triple super phosphate (TSP) fertilizers [3].

Soils of Pakistan are generally alkaline and calcareous in nature, where maize crop generally suffers from deficiency of essential nutrients like N, P and K. About 80 to $90 \%$ soils from arid and semiarid regions of the world, including 
Pakistan, are deficient in available nitrogen [4]. Various other factors which will affect the nitrogen availability is temperature, moisture content, $\mathrm{pH}$ of the soil and amount of clay minerals in the soil. Nitrogen is the most essential nutrient required for plant growth and is usually absorbed in nitrate form by plants [5] and it constitutes about $1.7 \%$ to $5.8 \%$ of dry weight of many plants. It is the also the important component of many nucleic acids, organic acids and many proteinaceous compounds, apart from this its plays a vital role in synthesis of chlorophyll, photosynthesis process and carbon dioxide $\left(\mathrm{CO}_{2}\right)$ assimilation [6]. Nitrogen also have synergistic relation with other nutrients like phosphorous, potassium and calcium and deficiency of nitrogen in soil will result the plants to suffer from others nutrients deficiency [7].

Nowadays the combine application of organic materials and inorganic fertilizers became the favorable method for farmers to enhance their crop yield and production growth. However, most of the researchers and farmers are unaware of that which is the best fertilizer integration ratio and what type of organic manure should be used for obtaining good fertile soil and economical crop yield. The vigorous application of organic and inorganic fertilizers to soil in greed of economical crop yield leads to demolition of fertility status of soil, Therefore the present study was initiated with an objective to study and compare various ratios of organic manures and its effect of chemical properties of post-harvest soil of District Peshawar, KPK, Pakistan.

\section{Materials and Method}

\subsection{Experimental Design and Treatments}

The experimental site is situated at $34.01^{\circ} \mathrm{N}$ latitude $72^{\circ} \mathrm{E}$ longitudes having an altitude of $298 \mathrm{~m}$ above sea. The area has continental climate type. Total 9 treatments were used and each treatment was replicated five times thus making 45 experimental units. Each of the plot size was $12 \mathrm{~m}^{2}(4 \mathrm{~m} \mathrm{x}$ $3 \mathrm{~m})$. The experimental units were designed according to Randomize Complete Block design. Different types of organic manures were also applied to specified plots before one week of sowing whereas $50 \%$ Urea was added to soil in split doses at time of sowing and fist irrigation. The combination of treatments is shown in table 1.

Table 1. Treatments combination of the experiment.

\begin{tabular}{lllll}
\hline Treatments & \%N from Organic manure (O. M) & \% N from Urea & Urea: O. M (based on \%N) & Required amount of N (kg/ha) \\
\hline T1 (Control) & 0 & $100 \%$ & $0: 1$ & $1: 1$ \\
T2 & $50 \%$ N from SSB & $50 \%$ & $1: 1$ & 120 \\
T3 & $50 \% \mathrm{~N}$ from SCB & $50 \%$ & $1: 1$ & 120 \\
T4 & $50 \% \mathrm{~N}$ from PL & $50 \%$ & $1: 1$ & 120 \\
T5 & $50 \% \mathrm{~N}$ from FYM & $50 \%$ & $3: 1$ & 120 \\
T6 & $25 \% \mathrm{~N}$ from SSB & $75 \%$ & $3: 1$ & 120 \\
T7 & $25 \% \mathrm{~N}$ from SCB & $75 \%$ & $3: 1$ & 120 \\
T8 & $25 \% \mathrm{~N}$ from PL & $75 \%$ & $3: 1$ & 120 \\
T9 & $75 \% \mathrm{~N}$ from FYM & 0 & $1: 0$ & 120 \\
T10 & $100 \%$ N from SSB & 0 & $1: 0$ & 120 \\
T11 & $100 \%$ N from SCB & 0 & $1: 0$ & 120 \\
T12 & $100 \%$ from PL & 0 & $1: 0$ & 120 \\
T13 & $100 \%$ N from FYM & & \\
\hline
\end{tabular}

Abbreviations.

$\mathrm{N}=$ Nitrogen.

$\mathrm{SSB}=$ Soya bean straw biochar.

$\mathrm{SCB}=$ Sugar cane bagasse.

$\mathrm{PL}=$ Poultry Litter.

FYM=Farm yard Manure.

\subsection{Soil Sampling and Sample Analysis}

The composite soil sample $(0-15 \mathrm{~cm})$ was taken from experimental site before initiation of the experiment and separate soil samples were collected from depth of $15-30 \mathrm{~cm}$ after harvest of the maize crop. The samples were air dried and ground to pass through 2- $\mathrm{mm}$ sieve. Soil color was recognized according to Munsil Color Chart notation. The prepared soil samples were then analyzed for various physical and chemical properties such as soil texture by method of Gee and Baudur [8], $\mathrm{pH}$ of soil by method of Mclean [9], electrical conductivity (EC) by method proposed by Black [10], Organic matter content by method of Nelson and Sommers [11], total nitrogen by method of Bremener and Mulveney [12]. Extractable phosphorous and potassium by method proposed by Soltanpur [13] in the laboratory in order to evaluate the physical and chemical properties of the experimental location and its data is shown in the table 2.

The data of the following soil parameters were recorded after the crop harvest:

i. $\mathrm{pH}$ of the post-harvest soil.

ii. $\mathrm{EC}\left(\mathrm{dS} \mathrm{m}^{-1}\right)$ of the post-harvest soil

iii.Bulk density of soil.

iv. Organic matter content the post-harvest soil

v. Total Nitrogen content of the soil the post-harvest soil

\subsection{Statistical Analysis}

ANOVA procedures suitable for RCB design was used for data statistical analysis. Means value were compared using LSD test at $p<0.05$ when the $F$ values were significant [14]. 
The data was then also analyzed by computer software programs such as Excel 2014 and STATISTIX 10.1.

\section{Results and Discussion}

\subsection{Initial Chemical Status of Soil}

The analysis of soil sample taken before the initiation of the experiment showed that the soil has $18.8 \%$ lime and was slightly alkaline $(\mathrm{pH}=7.75)$, non-saline $\left(\mathrm{E} . \mathrm{C}=2.17 \mathrm{dSm}^{-1}\right)$, silty loam in texture and was deficit in organic matter $(0.81 \%)$, total nitrogen $(0.46 \%)$, extractable phosphorous $(3.73 \mathrm{~kg} / \mathrm{ha})$ and potassium $(91.65 \mathrm{~kg} / \mathrm{ha})$.

Table 2. Physical and chemical properties of experimental site.

\begin{tabular}{ll}
\hline Physical and Chemical Property & Value and Unit \\
\hline Soil Texture & Silty Loam \\
$\mathrm{pH}$ & 7.90 \\
Electrical conductivity & $2.17 \mathrm{dSm}^{-1}$ \\
\hline
\end{tabular}

\begin{tabular}{ll}
\hline Physical and Chemical Property & Value and Unit \\
\hline Lime & $18.8 \%$ \\
Organic matter & $0.81 \%$ \\
Bulk density & $1.25 \%$ \\
Total Nitrogen & $0.46 \%$ \\
Extractable Phosphorous & $3.73 \mathrm{~kg} / \mathrm{ha}$ \\
Extractable Potassium & $91.65 \mathrm{~kg} / \mathrm{ha}$ \\
\hline
\end{tabular}

\subsection{Nutrient Content of Organic Manures}

The samples taken from various types of organic manures used in the experiment and was analyzed for different chemical properties and its data is shown in table 3. It shows that all the organic manures were non saline and slightly alkaline in nature. Maximum organic carbon $(43.7 \%)$, total potassium content $(1.58 \%)$ was recorded for soya bean straw biochar (SSB), whereas maximum total nitrogen $(1.58 \%)$ and total phosphorous content $(2.12 \%)$ was analyzed for poultry litter (PL). Wider CN ratio (32.6) was calculated for farmyard manure (FYM).

Table 3. Chemical Properties of organic manures used in the experiment.

\begin{tabular}{lllll}
\hline \multirow{2}{*}{ Chemical Property } & \multicolumn{2}{l}{ Different types of organic manures } & PL & FYM \\
\cline { 2 - 5 } & SSB & SCB & 7.60 & 7.20 \\
\hline $\mathrm{pH}$ & 7.90 & 7.68 & 3.08 & 2.66 \\
Electrical conductivity $\left(\mathrm{dsm}^{-1}\right)$ & 2.86 & 3.11 & 35.1 & 28.9 \\
Organic carbon (\%) & 43.7 & 28.3 & 22.2 & 32.6 \\
CN ratio & 29.3 & 25.7 & 1.58 & 0.86 \\
Total Nitrogen (\%) & 1.14 & 1.10 & 2.12 & 1.14 \\
Total Phosphorous (\%) & 0.74 & 0.70 & 1.34 & 1.20 \\
Total Potassium (\%) & 1.58 & 1.48 & & \\
\hline
\end{tabular}

\section{3. pH and E. C $\left(\mathrm{SSm}^{-1}\right)$ of Post-harvest Soil}

The mean values in table 4 shows that $\mathrm{pH}$ and electrical conductivity (E. C) of post-harvest soil of maize was significantly affected $(\mathrm{P}>0.05)$ by various treatments of organic manures of various sources applied alone and in combination with urea. The highest $\mathrm{pH}$ (7.80) was noted for T10 treatment receiving $100 \% \mathrm{~N}$ from SSB followed by treatment $\mathrm{T} 11$ receiving $100 \% \mathrm{~N}$ from alone SCB. which has given the $\mathrm{pH}$ of 7.78. While lowest $\mathrm{pH}$ (7.50) was calculated for treatment T2 receiving Urea and SSB in 1:1 ratio. The main reason for the decrease in $\mathrm{pH}$ (7.90) before initiation of the experiment) is due to release of various acids during mineralization process in soil [16]. The application of organic manures might have increased the activity of microbes in rhizosphere thus making the conditions favorable for mineralization of nitrogen, also urea upon solubilization give rise $\mathrm{H}+$ ions in soil thus lowering the $\mathrm{pH}$ of rhizosphere soil. The ideal $\mathrm{pH}$ for plant growth is from 6.50 to 7.50 meaning that combined application of urea and organic mediates the $\mathrm{pH}$ of soil thus making it favorable for supreme crop production. Mean values of Electrical conductivity (E. C) in table 4 shows that all the treatments have significantly enhanced the $\mathrm{E}$. $\mathrm{C}$ of post-harvest soil of maize. In case of electrical conductivity (E. C) maximum value $(0.53 \mathrm{dS} / \mathrm{m})$ was noted for T4 receiving 1:1 ratio of Urea and poultry litter (PL) successfully followed by results $(0.51 \mathrm{dS} / \mathrm{m})$ from $\mathrm{T} 3$ receiving Urea $+\mathrm{SCB}$ in 1:1 ratio While the minimum E. C of
$0.30 \mathrm{dS} / \mathrm{m}$ was recorded for $\mathrm{T} 1$ treatment control receiving only $100 \%$ Urea. The possible reasons may be that decomposition of organic manure give rise to certain organic acids by activity of microbes which plays a vital role in solubilization of inorganic fertilizers and thus releasing soluble salts to soil resulting in increase of electrical conductivity of soil. These results show resemblance to findings of [15]; [16] who examined variations in $\mathrm{pH}$ and $\mathrm{E}$. $\mathrm{C}$ of soil when organic manures along with mineral fertilizers was added to it.

\subsection{Organic Matter, Total Nitrogen and Bulk Density of Post-harvest Soil}

Mean values of organic matter, total nitrogen content and bulk density of after harvest soil in table 4 shows that various types of organic manures supplemented with urea in dynamic ratios has significantly affected $(\mathrm{P}>0.05)$ the of organic matter and total nitrogen content while the bulk density was non significantly affected. Maximum organic matter concentration was $2.88 \%$ which was calculated for $\mathrm{T} 12$ receiving alone poultry litter $(100 \% \mathrm{~N}$ from $\mathrm{PL})$ significantly tailed by $(2.86 \%)$ given by T10 receiving alone soya bean straw biochar $(100 \% \mathrm{~N}$ from SSB). While the minimum organic matter concentration of was recorded for was recorded for T1 (control having alone Urea). Total nitrogen content of post-harvest of soil was significantly influenced by different treatments used in the experiment. Maximum N concentration $(0.46 \%)$ was obtained from treatment T2 getting urea and SSB in 1:1 ratio (based 
on $\% \mathrm{~N})$, significantly followed by $(0.45 \%)$ treatment $\mathrm{T} 4$ receiving Urea and PL in 1:1 ratio and treatment T8 receiving urea and PL in 1:3 ratio, while minimum total nitrogen content of $29 \%$ was found for treatment T13 receiving alone FYM as shown in table 4.

By comparing the performance of various treatments groups, maximum values of organic matter concentrations were recorded for treatments receiving 1:0 combinations (T10, T11, T12 and T13). In case of total nitrogen content, maximum values were obtained by treatments having $1: 1$ ratio combination (T2, T3, T4 and T5). Presumably it may be due to better mineralization of nitrogen in urea offered by different organic manures. The enhanced microbial activity in soil will convert the organic $\mathrm{N}$ into exchangeable form. Organic manures like biochar plays a vital role in retaining the soil nutrients from losses by increasing water and nutrient holding capacity of soil. The above results lie in par with [17, 18] who concluded that soil organic matter and nitrogen content can be enhanced by integration of organic manures and mineral fertilizers.

Table 4. pH, E. C, total nitrogen content, organic matter content and bulk density of post-harvest soil as affected by treatments having integration of various organic manures and urea in diverse ratios.

\begin{tabular}{|c|c|c|c|c|c|}
\hline \multirow{2}{*}{ Treatments } & pH & E. C & Organic matter content & Total $\mathbf{N}$ in Soil & Bulk Density \\
\hline & - & $\mathrm{dSm}^{-1}$ & $\%$ & $\%$ & $\%$ \\
\hline $\mathrm{T} 1=$ Alone Urea (control) & $7.60 \mathrm{cde}$ & $0.30 \mathrm{f}$ & $1.10 \mathrm{f}$ & $0.35 \mathrm{~cd}$ & 1.25 \\
\hline T3=Urea + SCB $(1: 1)$ & $7.52 \mathrm{ef}$ & $0.51 \mathrm{ab}$ & $2.48 \mathrm{~cd}$ & $0.42 b$ & 1.25 \\
\hline T4=Urea+PL (1:1) & $7.53 \mathrm{e}$ & $0.53 a$ & $2.54 \mathrm{c}$ & $0.45 \mathrm{ab}$ & 1.24 \\
\hline T5=Urea+FYM $(1: 1)$ & $7.60 \mathrm{cde}$ & $0.48 b c$ & $2.24 \mathrm{de}$ & $0.33 \mathrm{de}$ & 1.24 \\
\hline T6=Urea+SSB (3:1) & $7.55 \mathrm{de}$ & $0.43 \mathrm{de}$ & $2.12 \mathrm{def}$ & $0.35 \mathrm{~d}$ & 1.23 \\
\hline $\mathrm{T} 7=$ Urea $+\mathrm{SCB}(3: 1)$ & $7.68 \mathrm{bc}$ & $0.46 \mathrm{~cd}$ & $2.09 \mathrm{e}$ & $0.40 \mathrm{bc}$ & 1.25 \\
\hline $\mathrm{T} 8=$ Urea + PL $(3: 1)$ & $7.55 \mathrm{de}$ & $0.46 \mathrm{~cd}$ & $2.20 \mathrm{de}$ & $0.45 \mathrm{ab}$ & 1.24 \\
\hline T9=Urea+FYM (3:1) & $7.63 \mathrm{~cd}$ & $0.40 \mathrm{def}$ & $1.89 \mathrm{ef}$ & $0.31 \mathrm{e}$ & 1.25 \\
\hline $\mathrm{T} 10=$ Alone SSB & $7.80 \mathrm{a}$ & $0.37 \mathrm{ef}$ & $2.86 \mathrm{a}$ & $0.39 \mathrm{c}$ & 1.25 \\
\hline T11=Alone SCB & $7.78 \mathrm{ab}$ & $0.40 \mathrm{def}$ & $2.72 \mathrm{ab}$ & $0.37 \mathrm{~cd}$ & 1.24 \\
\hline $\mathrm{T} 12=$ Alone PL & 7.72abc & $0.38 \mathrm{ef}$ & $2.88 \mathrm{a}$ & $0.44 \mathrm{abc}$ & 1.25 \\
\hline LSD & $1.96^{* *}$ & $1.48 *$ & $1.77 * *$ & $0.17 * *$ & NS \\
\hline
\end{tabular}

NS (Non-significant) if $\mathrm{P}>0.05 ; *$ if $\mathrm{P} \leq 0.05 ; * *$ if $\mathrm{P} \leq 0.01 ; * * *$ if $\mathrm{P} \leq 0.001$.

Abbreviations.

$\mathrm{SSB}=$ Soya bean straw biochar.

$\mathrm{SCB}=$ Sugar cane bagasse.

$\mathrm{PL}=$ Poultry Litter.

FYM=Farm yard Manure.

LSD $=$ Least Significant Difference.

\section{Conclusions}

From the present study it is concluded that all the treatments receiving alone and integration of organic and inorganic fertilizers in diverse ratios have significantly affected the chemical properties of post-harvest soil of maize crop such as $\mathrm{pH}, \mathrm{E}$. C, total nitrogen content and organic matter content while bulk density was non-significant. By comparing the performance of various treatments groups, maximum values of organic matter concentrations were recorded for treatments receiving 1:0 combinations (T10, T11, T12 and T13). In case of total nitrogen content, maximum values were obtained by treatments having 1:1 ratio combination (T2, T3, T4 and T5). From the present study it was concluded that all the treatments except control have altered the chemical status of soil to a favorable soil enviro responsive microbial activity and plant growth. Such studies on different soil series under different climatic conditions is advised for wide spread application and authorization of results.

\section{References}

[1] Okalebo, J. R. 1987. Maize response to three high analysis phosphate fertilizers in some soils of East Africa. Part 1. Effects on growth. E. Afr. Agric. and For. Journal, 43: 75-83.

[2] Mokwunye, U. and Bationo, A. 2002. Meeting the phosphorus needs of the soil and crops in West Africa. CAB Publishing, Wallingford, UK.

[3] Smalling, E. M. A., Nandwa, S. M. and Janssen, B. H. 1997. Soil fertility in Africa is at stake. In: Buresh, R. J., Sanchez, P. A. and Calhoun, F. (eds), Replenishing soil fertility in Africa. SSSASpec. Publ. 51, A, Madison, WI, pp. 47-61.

[4] NFDC. 2001. Balanced fertilization through phosphate promotion. Project terminal report. NFDC, Islamabad, Pakistan.

[5] Jasso-Chaverria C, Hochmuth GJ, Hochmuth RC, Sargent SA. 2005. Fruit yield, size, and colour responses of two Greenhouse cucumber types to nitrogen fertilization in perlite soilless culture. Horticulture Technology. 15: 565. 
[6] Tisdale SL, Nelson WL. 1990. Soil fertilizer and effect of magnesium on the yield and chemical of crops. Michigan Agricultural Experimental Statistics. Bull Press, Mechigan, American, p29-31.

[7] Brady C. 1984. The nature and properties of soils. Macmillan Publishing Company, New York

[8] Gee, G. W and J. W. Bauder. 1986. Particle-size Analysis. In: Klute, A. (Ed.) Methods of soil analysis. Physical and Mineralogical methods. Agronomy monograph 9 (2ed). Amer. Soc. Agron. Madison. pp 383-411.

[9] Mclean, E. O. 1982. Soil pH and Lime Requirement. In: Page, A. L., Ed., Methods of Soil Analysis. Part 2. Chemical and Microbiological Properties, American Society of Agronomy, Soil Science Society of America, Madison, 199-224.

[10] Black, C. A. 1965. Methods of Soil Analysis: Part I, Physical and Mineralogical Properties. American Society of Agronomy, Madison, Wisconsin.

[11] Nelson, D. W and I. E. Sommer. 1982. Total carbon, Organic carbon and organic matter. pp. 539-577: In: A. L. page, R. H. Miller and D. R. Keeny, (ed.) Methods of soil analysis part 2 2nd ed. Am. Soc. Agron. Madison, Wisconsin.

[12] Bremner, J. M. and C. S. Mulvaney 1982 Total nitrogen Methods of Soil Analysis, Part 2, Chemical and microbiological properties American Society of Agronomy and Soil Science Society of America, Madison, pp. 11191123 .
[13] Soltanpur, P. N., and A. P Schwab. 1997. A new soil test from simultaneous extraction of macro and micro nutrients in alkaline soils. Comm. Soil. Sci. Plant analysis. 8: 195-207.

[14] Jan, M. T., P. Shah, P. A. Hollington, M. J. Khan and Q. Sohail. 2009. Agriculture Research: Design and Analysis. Dept. of Agronomy, KPK Agric. Uni. Peshawar, Pakistan.

[15] Kapoor KK, Mishra MM, Kukreja K (1989) Phosphate solubilization by soil microorganisms: A review. Indian J Microbiol 29: 119-127.

[16] Mussaddiq, K. K., Muhammad, D., Qureshi S. R., Nawaz S and Ishaq, F. 2019. Impact of Phosphorite on $\mathrm{pH}$, ElectricalConductivity and Water Soluble Phosphorous Extracted from Incubated Citrus Waste Compost. Modern Chemistry. 7 (4): 109-113. doi: 10. 11648/j. mc. 20190704. 14.

[17] E. Ndor, S. M. Amana and C. L. A. Asadu. 2015. Effect of Biochar on Soil Properties and Organic Carbon Sink in Degraded Soil of Southern Guinea Savanna Zone, Nigeria. International Journal of Plant \& Soil Science. 4 (3): 252-258.

[18] Ali, W., Ali, M., Iqbal, J., Khalil M. K and Ahmad, Z. 2019. Impact of Zinc and Organic Manure on Wheat Productivity and Soil Fertility. Adv CropSci Tech 7: 414. doi: 10. 4172/2329-8863. 1000414. 